\title{
Road Construction Concession in Bosnia and Herzegovina
}

\section{Ivana Domljan}

Faculty of Civil Engineering, University of Mostar, Ph.D C.E. ivana.domljan@gf.sum.ba

Marijana Prkačin Goluža, M.Eng.C.E

JP Autoceste FBiH

marijana.prkacin.goluza@gf3.sum.ba

\begin{abstract}
The paper examines the causes of insufficient implementation of public-private partnership projects in the field of road infrastructure. The aim of this paper is to present the possibility of using the public-private partnership concession in Bosnia and Herzegovina, especially in the Federation of Bosnia and Herzegovina, in the construction of road infrastructure. The results of the research can be useful to public bodies in implementing the first phase of the life cycle of a public-private partnership project, i.e. in preparing the necessary study documentation, and then selecting potential public-private partnership projects in road infrastructure in the Federation of Bosnia and Herzegovina.
\end{abstract}

Key words: public-private partnership, project finance, concession, road infrastructure, risks

\section{Koncesija u cestogradnji Bosne i Hercegovine}

Sažetak: U radu se istražuju uzroci nedovoljne realizacije projekata javno-privatnog partnerstva u oblasti cestovne infrastrukture. Cilj rada je prikazati mogućnost korištenja koncesije kao oblika javno-privatnog partnerstva u izgradnji cestovne infrastrukture u Bosni i Hercegovini, posebice u Federaciji Bosne i Hercegovine.

Rezultati istraživanja mogu biti od koristi javnim tijelima u provođenju prve faze životnog vijeka projekta javno-privatnog partnerstva, odnosno u izradi potrebne studijske dokumentacije, te potom odabiru potencijalnih projekata javno-privatnog partnerstva $u$ cestovnoj infrastrukturi u Federaciji Bosni i Hercegovini.

Ključne riječi: javno-privatno partnerstvo, projektne financije, koncesija, cestovna infrastruktura, rizici 


\section{INTRODUCTION}

Three financing models are used in the construction, management and maintenance of infrastructure in a market economy: state (public) financing, private and mixed (publicprivate) financing.

The traditional financing model is usually used in the financing of road infrastructure projects. In its implementation, the public sector is exposed to high risks in the project development phase, which then reflects on the construction and maintenance phases. Public sector risks include risks related to changes in legislation, residual value, force majeure effects, market conditions, service availability, quality of the completed project, maintenance of the facility, changes of governing political actors, relations with local communities, environmental disasters, etc. while the private sector takes the risk of road infrastructure construction.

The lack of financial resources and/or expertise and experience in the construction of infrastructure facilities faced by the public sector has led to the need to use new financing models such as mixed financing, or joint action of the public and private sectors.

Mixed financing is implemented using the project financing technique (Fig. 1), the basic characteristic of which is that the development of the project is mainly financed by a loan and less often by issuing debt securities (bonds) that are repaid from the revenues the project plans to generate, while project assets are used as a secondary source for settlement of obligations (as a guarantee). This model of public-private partnership (PPP) confronts the two most important interests of the stakeholders - the public sector, which as a client seeks to use taxpayers' money based on the principle of getting the highest value for money, and the private sector, which as a bidder wants to develop the project and maximize long-term profits (Domljan, 2008a).

In the case of a concession contract, the responsibility for the delivery of the service is mainly on the private partner, which is formally and legally responsible for undertaking and financing investments and achieving the established standard of service. In return, the private partner is entitled to revenues from the service provided, in some cases to subsidies, based on established service rates.

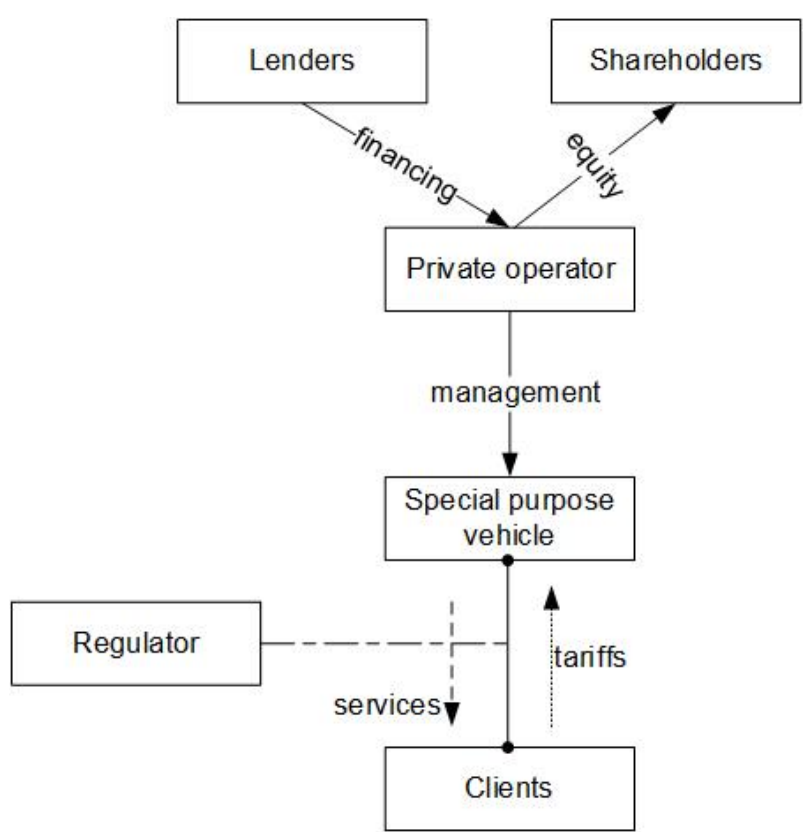

Figure 1. Project finance model 
Domljan, I., Prkačin Goluža, M.

Road Construction Concession in Bosnia and Herzegovina

As a developing country and country on the path to membership in the European Union $(E U)$, Bosnia and Herzegovina $(\mathrm{BiH})$ needs to strengthen its legal and regulatory framework, harmonize them with EU rules and thus create adequate formal and legal conditions for the emergence and development of public-private partnership in the development of infrastructure.

In addition to harmonizing the legal and regulatory framework in the field of concessions, it is also necessary to develop expertise for making assessments and selecting potential projects for application of concessions and for conducting in-depth studies. It is only after the necessary analyses are conducted and feasibility studies are completed that a financial analysis can be carried out, on the basis of which a final decision on the (non) implementation of the concession in the construction of road infrastructure will be made.

\section{RISKS OF PRIVATE ROAD CONSTRUCTION FINANCING}

If political, legal and regulatory risks are ignored, the main commercial risks faced by publicprivate partnership projects in road construction are: (i) traffic and revenue and (ii) construction costs (Li, Mao, Dai and Zhang, 2018).

The relevant risks should be considered in detail in the feasibility study, which includes: (i) traffic and revenue study based on appropriate forecasts, (ii) cost-benefit analysis in order to determine the public (economic, social and environmental) rate of return, or benefits for users (travel time and safety, etc.) as well as for non-users (reduction of pollution, noise, threats to landscape, etc.) and induced benefits (improved access, development of economic activities, land uses, increased employment, etc.), and (iii) financial analysis, which considers financing options, determines the rate of private (financial) return, "bankability" of the project and debt repayment service (Domljan, 2008b).

In many cases, the most uncertain element of a feasibility study is the traffic and revenue forecasting. Forecasts are based on the traffic volume and its growth based on the existing network. Traffic counting and surveys conducted in the influence zone of the planned highway provide data for establishing the origin-destination travels as well as the purpose of travel (work, recreation, business trip, etc.). The use of studies of manifested preferences or evidence from other highways can help in assessing the existing and future willingness to pay tolls for certain highway and market segments.

Analyses of traffic and revenue sensitivity to tolls are an integral part of the feasibility studies. For example, in the case of the Dulles Greenway highway in the U.S., traffic forecasts did not adequately consider the sensitivity to toll, and it happened that road users were discouraged by its initial amount, which was twice as high as that of the connecting Dulles Toll road. In another, positive example, for many years the JHPC (Japan Highway Public Corporation) perfected the equation of the relationship between toll rate and diversion rate to improve the accuracy of traffic forecasting in relation to toll elasticity (Estache, Romero, and Strong, 2000). Several very interesting case studies related to highways in China can be found in Li, Mao, Dai and Zhang (2018).

The average annual daily traffic (AADT) of 10,000 is the threshold for attracting the private sector and private capital. AADT below this value requires government support (guarantees, grants, etc.). National, high-traffic highways (with at least 15,000 vehicles per day) are a good norm for a profitable highway. Consequently, roughly speaking, a traffic of 10,000 to 15,000 vehicles per day is required in order for traffic and revenues to cover all costs. Coverage of operating costs requires at least 3,500 vehicles per day, while recovery of toll collection costs requires approximately 1,500 vehicles per day (Estache, Romero, and Strong, 2000). 
Domljan, I., Prkačin Goluža, M.

Road Construction Concession in Bosnia and Herzegovina

Traffic volume is sensitive to economic growth and income. ${ }^{1}$ Motorization and vehiclekilometers traveled typically increase faster than income. This high income elasticity, especially for leisure trips, makes toll highways especially sensitive to macroeconomic conditions. In Hungary, the M1 highway reached only $50 \%$ of expected traffic in the first year of operation, since the expected economic growth did not occur (and there were also less than expected diversions from other roads, since the government did not keep its promise to limit truck traffic through competitive, public roads; by the way, even the model based on which the predictions were developed used parameters suitable for France but not for Hungary).

Major errors in estimating traffic volume and revenue occur not only in transition countries, but also in the most developed countries. For example, in the U.S., the Dulles Greenway achieved one-third of its expected daily volume outside of Washington DC. Even after a toll reduction of $40 \%$, it achieved only two-thirds of its originally forecast traffic volume (Estache, Romero, and Strong, 2000).

Examples of projects that have dramatically overestimated the volume of demand are some Mexican projects where the actual traffic volume reached only one-fifth of the forecast traffic. Analytical studies did not consider differences in travel by time periods (days, seasons) or by vehicle type and type of travel. The shortcomings of such studies are generally attributed to a lack of expertise in concessionaires, financiers, and their consultants (Small, and C. Winston, 1999).

The factors to be kept in mind when estimating traffic volume and revenue are the number and quality of alternative roads and their development, and the connection of the intended highway with other road routes within a developing road network, with and without tolls. It is also often forgotten that toll highways serve different groups of users, including the poor in rural areas who cannot afford to pay tolls with which operators would cover investments in these market segments. According to some estimates, the standard traffic models used in forecasting demand are too generalized and do not sufficiently acknowledge the behavioral changes caused by toll highways (Piron, 1999; Castelblanco et al., 2020).

Construction cost risks are risks that a highway will not be constructed within a given budget, a given time frame, or that it will not meet certain quality standards. They are especially high for independent toll highways, i.e. those that are not included in the toll highway system. The physical characteristics are the primary factors determining the amount of costs, while important factors also include the type of project (new highway, expansion/repair of existing highway; independent highway or as part of a network); length, capacity and design; geographical and geological aspects and toll collection mechanism (Estache, Romero, and Strong, 2000; Khmel and Zhao, 2015).

\section{APPLYING A CONCESSION IN ROAD INFRASTRUCTURE PROJECTS IN BiH}

In Bosnia and Herzegovina, concessions are regulated by the Law on Concessions of $\mathrm{BiH}$ ("Official Gazette of BiH", number 32/02, 56/04), laws at the entity level, for example, the Law on Concessions of $\mathrm{FBiH}$, ("Official Gazette of the Federation of $\mathrm{BiH}^{2}$, number 40/02 and $61 / 06)$, and laws of the counties in the case of the Federation of $\mathrm{BiH}^{2}{ }^{2}$

\footnotetext{
${ }^{1}$ Taking a global view, research shows that investments in road construction should be about US\$ 900 billion per year in order to keep pace with the global growth rate, which means that the annual allocations are lower than necessary by US\$ 180 billion, or 20\% (Garemo, Hjerpe and Halleman, 2018).

${ }^{2}$ Bylaws related to concessions at the $\mathrm{FBiH}$ level are: (i) Rules on the concession awarding procedure (Official Gazette of $\mathrm{FBiH}$, no. 68/06 and 87/11), (ii) Rules on establishing the concession fee (Official
} 
Domljan, I., Prkačin Goluža, M.

Road Construction Concession in Bosnia and Herzegovina

At the level of $\mathrm{BiH}$, the competence for awarding concessions belongs to the Council of Ministers of $\mathrm{BiH}$, which at the proposal of the relevant ministry initiates the procedure of awarding the concession and makes a decision on the type, subject and scope of the concession being awarded, which is then approved by the Parliamentary Assembly of BiH.

The concession awarding procedure is conducted by the concessor, appointed by the Council of Ministers of $\mathrm{BiH}$, and the concessor can be a ministry or other body of $\mathrm{BiH}$.

Supervision over the implementation of the awarded concession contract is performed by the BiH Concessions Commission.

The concession awarding procedure can be carried out through an "unsolicited bid" of interested bidders or through a "public invitation/tender", when the concessor announces a public invitation/tender and collects bids for the project for which it intends to conclude a concession contract.

In the case of an unsolicited bid, the Commission is also competent to give an authorization for direct negotiations between the bidder for the concession project and the relevant state ministry, after the ministry confirms that there is a "public interest" in the concession. Other tasks of the Commission related to the issuance of the concession are to:

i. adopt a "Document on the policy of awarding concessions in $\mathrm{BiH}^{2}$, and monitor the implementation of the document concerned;

ii. monitor the performance of the concessionaire throughout the duration of the concession contract, approve the standard contract terms and conditions for the provision of services to consumers, and consider consumer complaints;

iii. give regulatory approvals in the procedure of awarding concessions at different stages of the procedure, depending on whether it is a procedure of selecting a concessionaire through a public invitation/tender or through an unsolicited bid; and

iv. give approval for:

a. feasibility studies

b. tender requirements and

c. draft concession contract.

According to the Law on Concessions of $\mathrm{FBiH}$, the Government of the Federation of $\mathrm{BiH}$ has the authority to award concessions at the $\mathrm{FBiH}$ level. At the proposal of the relevant ministry, it initiates the procedure of awarding the concession and makes a decision on the type, subject and scope of the concession being awarded.

Professional activities related to the preparation of tenders and decisions on awarding concessions for highways, expressways and some structures on main roads are performed by the public companies Autoceste $\mathrm{FBiH}$ and Ceste $\mathrm{FBiH}$. The decision to award a concession is made on the basis of a conducted public tender or negotiations with an unsolicited bidder.

The current legislation in the field of concessions in Bosnia and Herzegovina, but also in the Federation of $\mathrm{BiH}$, is underdeveloped, not adapted for use in complex projects, primarily due to leaving the possibility of different interpretations of its parts, underdevelopment of the preparatory phase in which the public sector plays a key role. underdevelopment of the tender procedure implementation stage, then concession contract monitoring.

The field of concessions is very significant and as such is part of the negotiations on the accession of Bosnia and Herzegovina to the European Union (Negotiations Chapter 5 Public Procurement). In the process, Bosnia and Herzegovina will have to harmonize its legislation with the rules of the European Union (EU), primarily with Directive 2014/23/EU of the European Parliament and of the Council of 26 February 2014 on the award of concession contracts. ${ }^{3}$

Gazette of FBiH no. 67/06) and the Document on Concession Award Policy (Official Gazette of FBiH no. $64 / 05,8 / 11$ and $10 / 11)$.

${ }^{3}$ Available on: http://data.europa.eu/eli/ dir/2014/23/2016-01-01 
Domljan, I., Prkačin Goluža, M.

Road Construction Concession in Bosnia and Herzegovina

The current legislation on concessions in $\mathrm{BiH}$ is not brought into line with OECD principles. OECD principles and EU rules advocate the principle of equal treatment, nondiscrimination and transparency, both in public procurement and in the award of concessions. Legislation on concessions in $\mathrm{BiH}$ has been amended since 2002, but is still not in line with the current EU Directive.

According to the annual activity plan of the $\mathrm{BiH}$ Concessions Commission for 2020. It is planned to harmonize the legislation with Directive 2014/23/EU, to educate public servants on concessions, as well as to draft a Document on the policy of awarding concessions in line with the EU Directive.

The basic shortcomings of the current legislation in $\mathrm{BiH}$ :

- The Law on Concessions of $\mathrm{BiH}$ and the Law on Concessions of $\mathrm{FBiH}$ do not respect the basic principle for procurement of works and services according to EU rules and OECD principles, i.e. the principle of equal treatment, non-discrimination and transparency;

- There is no register of concessions in $\mathrm{BiH}$ and $\mathrm{FBiH}$;

- In the legislation, there is no announcement on the intention to award a concession;

- The Law on Concessions of $\mathrm{BiH}$ and the Law on Concessions of FBiH introduce the concept of unsolicited bid, which is contrary to EU rules. By putting the concessor under obligation to announce the intention to award the concession, Directive 2014/23/EU does not leave the possibility of an unsolicited bid for the concession, as prescribed by the current legislation in $\mathrm{BiH}$;

- The current legislation in $\mathrm{BiH}$ does not make it possible to make a change of the awarded concession under defined conditions, without the need to award a new concession;

- The legislation on concessions in $\mathrm{BiH}$ and $\mathrm{FBiH}$ does not define the types of procedures for conducting tenders for the award of concessions.

Based on the previously defined inconsistencies of the current legislation, it can be concluded that a concession contract can be concluded and implemented in $\mathrm{BiH}$ and $\mathrm{FBiH}$, but it would not be in accordance with EU rules and OECD principles.

The European PPP Expertise Center (EPEC), established by the European Commission and the European Investment Bank and open for membership of the competent bodies for public-private partnerships of EU member states and EU membership candidate states, published a handbook for preparation of public-private partnership projects in 2010 and supplemented it in 2011.

Comparing the legislative and non-legislative regulations on concessions in $\mathrm{BiH}$ and $\mathrm{FBiH}$ with this handbook, it can be concluded that the legislative regulations need to define how to implement the preparation stage of PPP projects. Legislative regulations deal with the implementation stage of the concession award procedure and concession contracts. The project stage before the tender, or the stage of project selection and assessment, cost analysis, organizational preparation, is not covered by the legislation on concessions.

A well prepared feasibility study is the basis for a high-quality assessment for the use of a public-private partnership model in a potential project. Feasibility studies for the assessment of PPP projects should include at least the following: (i) a clear vision of the future public-private partnership model with a detailed proposal of the PPP model for the potential project, along with the legal details of the proposed PPP contract, (ii) PESTELI analysis and (iii) risk analysis, options analysis, profitability analysis, needs analysis, etc.

The feasibility studies developed for expressways in the FBiH are not fully adapted for use in PPP projects, or for assessment of PPP projects. They need to be amended in order to provide a basis for implementation of the first phase of project life cycle, i.e. for assessment of the use of the PPP model. 
Domljan, I., Prkačin Goluža, M.

Road Construction Concession in Bosnia and Herzegovina

Preliminary feasibility studies are prepared for individual sections of expressways on the basis of conceptual solutions. However, due to the additional elaboration of the project in the conceptual design stage, these studies are subject to major changes and their content is not adapted for use in PPP projects.

An overview of feasibility studies for expressways in the $\mathrm{FBiH}$, defined by the $\mathrm{FBiH}$ Transport Strategy, is given below.

Table 1. Overview of developed feasibility studies of expressways in the $\mathrm{FBiH}$ and necessary amendments for use in PPP projects

\begin{tabular}{|c|c|c|}
\hline $\begin{array}{l}\text { Ser. } \\
\text { no. }\end{array}$ & $\begin{array}{l}\text { Feasibility study for the } \\
\text { expressway }\end{array}$ & Comment \\
\hline 1. & $\begin{array}{l}\text { Lašva - Jajce - Ključ - Bihać } \\
\text { - border with Croatia }\end{array}$ & $\begin{array}{l}\text { - Feasibility study for the expressway section } \\
\text { Lašva - Nević Polje was approved by the } \\
\text { FBiH Concessions Commission. } \\
\text { Subsequently, a decision on financing from } \\
\text { own funds was made. } \\
\text { - For the expressway section Nević Polje - } \\
\text { Jajce, a feasibility study is developed, but it } \\
\text { needs to be adapted to the possible use in } \\
\text { PPP projects. It is necessary to clearly define } \\
\text { a possible PPP model, perform a PESTELI } \\
\text { analysis, option analysis, risk analysis and } \\
\text { other necessary assessments to make a } \\
\text { decision on the use of the PPP model. } \\
\text { - A feasibility study has not yet been prepared } \\
\text { for the expressway Jajce - Ključ - Bihać - } \\
\text { Croatian border. }\end{array}$ \\
\hline 2. & $\begin{array}{l}\text { Jajce - Donji Vakuf - } \\
\text { Bugojno - Kupres - Livno - } \\
\text { border with Croatia }\end{array}$ & $\begin{array}{l}\text { Feasibility study has not been prepared. The } \\
\text { content of the study needs to be adapted to } \\
\text { the possible use in PPP projects. }\end{array}$ \\
\hline 3. & $\begin{array}{l}\text { Bihać - Velika Kladuša - } \\
\text { border with Croatia }\end{array}$ & $\begin{array}{l}\text { - Feasibility study has not been prepared. The } \\
\text { content of the study needs to be adapted to } \\
\text { the possible use in PPP projects. }\end{array}$ \\
\hline 4. & $\begin{array}{l}\text { Mostar - Široki Brijeg - } \\
\text { Grude - border with Croatia }\end{array}$ & $\begin{array}{l}\text { - Feasibility study has not been prepared. The } \\
\text { content of the study needs to be adapted to } \\
\text { the possible use in PPP projects. } \\
\text { A preliminary feasibility study is developed, } \\
\text { but its content is not fully adequate and } \\
\text { sufficient for making a decision on the use of } \\
\text { the PPP model. }\end{array}$ \\
\hline 5. & $\begin{array}{lll}\text { Sarajevo } & - \text { Goražde } \\
\text { Višegrad } & - \\
\text { Serbia } & & \\
\end{array}$ & $\begin{array}{l}\text { - Feasibility study is developed for the } \\
\text { expressway section Hrenovica - Goražde } \\
\text { (Hranjen tunnel), which is under construction. }\end{array}$ \\
\hline
\end{tabular}

It is only after the traffic study and the feasibility study of these expressway sections are prepared that it will be possible to consider the possibility of using a PPP model on these projects with careful consideration of the economic situation of $\mathrm{FBiH}$ and the possibility of using budget resources for construction of the road infrastructure that is not part of Corridor 
Domljan, I., Prkačin Goluža, M.

Road Construction Concession in Bosnia and Herzegovina

$\mathrm{Vc}$, but is of exceptional importance for traffic connection of more developed $\mathrm{BiH}$ areas with Corridor Vc as the backbone of the state road network.

\section{EXPERIENCES IN ROAD INFRASTRUCTURE FINANCING IN THE FEDERATION OF BIH}

Transport sector projects are not awarded a single concession in the FBiH. The Concessions Commission approved the feasibility study for the highway on Corridor Vc in 2007.

In 2012, the Government of $\mathrm{FBiH}$ made a decision to establish public interest in the construction of the expressway Lašva - Vitez - Donji Vakuf.

The activities for awarding a concession for construction of the sections Tarčin - Ovčari and Rudanka - Medakovo, proposed by the Ministry of Transport and Communications, were discontinued in 2017.

So far, no activity has been initiated in the FBiH that would lead to planning of concessions for the construction of road infrastructure on the route of international corridors between $\mathrm{BiH}$ and some of the neighboring countries.

According to the plan for securing financial resources for the largest infrastructure project in $\mathrm{BiH}$, the highway on Corridor $\mathrm{Vc}$ through $\mathrm{BiH}$, it is clear that the traditional model of financing through loans, grants and own funds is used for construction of the Corridor.

Sources of financing for expressways that will be the connecting roads of Corridor Vc and other major state centers in the final road network have not been defined, except for the highway sections Lašva - Nević Polje and Hrenovica - Goražde.

A directorate for expressways in $\mathrm{BiH}$, the Public Company Autoceste $\mathrm{FBiH}$, is not able to provide financial resources for the construction of expressways.

The FBiH Transport Strategy from 2016 to 2030 specifies that in the $\mathrm{FBiH}$ the current model of financing highways and expressways has been exhausted and that new models of investment in construction are needed.

Consequently, expressway construction projects are potential projects for the award of concessions, or for the use of public-private partnership models in order for the public client to improve the road infrastructure operation service in $\mathrm{BiH}$ without the use of budget funds.

According to the FBiH Transport Strategy, the planned expressways connecting Corridor Vc with the neighboring countries Croatia and Serbia are:

- Lašva - Jajce - Ključ - Bihać - border with Croatia

- Jajce - Donji Vakuf - Bugojno - Kupres - Livno - border with Croatia

- Bihać - Velika Kladuša - border with Croatia

- Mostar - Široki Brijeg - Grude - border with Croatia

- Sarajevo - Goražde - Višegrad - border with Serbia.

Considering that these expressways are important and complex road infrastructure projects that connect Corridor Vc with other major cities in Bosnia and Herzegovina, and eventually with neighboring countries, they are potential priority projects for the use of publicprivate partnership models.

Bearing in mind that the project documentation necessary for construction has not yet been prepared for the expressways concerned, it is possible to manage the project development process for the use of a public-private partnership model from the very beginning of the project, i.e. from the project documentation development phase.

With regard to the early stage in the preparation of project documentation, it is possible to apply EU rules and OECD principles in these projects, primarily in the field of environmental protection, which requires project monitoring from the very idea for its realization. 
Domljan, I., Prkačin Goluža, M.

Road Construction Concession in Bosnia and Herzegovina

Complying with the provisions of the adopted Transport Strategy, and in order to use the benefits of concession contracts, BiH has initiated activities for extension of the SEETO network (South East Europe Transport Observatory) by including the planned expressways. It is only after these activities are completed that the possibility can be considered to negotiate about financing with the European Bank for Reconstruction and Development and/or the European Investment Bank as the largest creditors of the highway on Corridor Vc through $\mathrm{BiH}$. Certainly, before any activity, it is necessary to strengthen the legislation on concessions and adapt it to EU rules.

\section{CONCLUSION}

Bosnia and Herzegovina has elements of the legal and regulatory framework for the award of concessions in road infrastructure projects both at the state level and at the levels of entities and the Brčko District, and counties.

The Federation of $\mathrm{BiH}$ still does not have experience with application of concessions in road infrastructure projects, while the Republic of Srpska concluded the first concession contract in 2018.

Laws and bylaws for the award of concessions in the Federation of $\mathrm{BiH}$ need to be amended in terms of specifying the conditions for the award of concessions, and it is necessary to initiate activities and research that will help in adopting a strategic plan of priority road infrastructure projects for financing through public-private partnerships.

Regarding the accession of Bosnia and Herzegovina to the European Union, it is necessary to harmonize legislation with EU rules, as well as OECD principles. The shortcomings of the current legislation are registered in the paper and they can serve the state bodies and public administration to understand the procedure and speed up the harmonization of the field of concessions with EU rules and OECD principles.

The shortcomings of the feasibility studies of expressways in the $\mathrm{FBiH}$, required for the financial analysis of these projects and decision-making on the model of their financing, are also indicated in the paper. Existing feasibility studies of expressways need to be adapted to the possible application of PPP models.

\section{REFERENCES}

1. Castelblanco, G., Guevara, G., Mesa, H. and Flores, D.: Risk Allocation in Unsolicited and Solicited Road Public-Private Partnerships: Sustainability and Management Implications, Sustainability, 2020, 12(11):4478.

2. Domljan, I: Rizici privatnog financiranja gradnje cesta $s$ naplatom cestarina, Zbornik radova, 2. internacionalni naučno-stručni skup Građevinarstvo - nauka i praksa, Univerzitet u Podgorici, Crna Gora, 2008a.

3. Domljan I: Financial Challenges of Corridor Vc Motorway Construction in $\mathrm{BiH}, 22 \mathrm{nd}$ IPMA World Congress Project Management to Run, Roma, Italy, 2008b.

4. Estache A, Manuel Romero and John Strong: Toll Roads, in Antonio Estache and Ginés de Rus (eds.), Privatization and Regulation of Transport Infrastructure, The World Bank, Washington, D.C., 2000, pp. 235-305.

5. Garemo, N., Hjerpe, M. and Halleman, B.: A better road to the future - Improving the delivery of road infrastructure across the world. New York: McKinsey \& Company and International Road Federation, 2018.

6. Khmel, V. and Zhao, S.: Arrangement of Financing for Highway Infrastructure Projects under the Conditions of Public-Private Partnership, IATSS Research, 2015. 
Domljan, I., Prkačin Goluža, M.

Road Construction Concession in Bosnia and Herzegovina

7. Li, J. Mao, P., Dai, Z, and Zhang, J.: Traffic Allocation Mode of PPP Highway Project: A Risk Management Approach. Advances in Civil Engineering, 2018, Volume 2018, Article ID 7193948, https://doi.org/10.1155/2018/7193948.

8. Piron, V.: Urbain-Interurbain: La Problematique est devenue globale, Transports,1999, 393, January-February. pp. 25-42.

9. Small, K. and C. Winston, C.: The Demand for Transportation: Models and Applications, in J. A. Gomez-lbanez, W.B. Tye, and C. Winston (eds), Essays in Transportation Economics and Policy, The Brookings Institution, Washington, D.C., 1999, pp. 11-55 